\title{
Global Food Crisis: Public Capital Expenditure and Agricultural Output in Nigeria
}

\author{
Suleiman G. Purokayo (Corresponding author) \& Aminu Umaru \\ Department of Economics, Federal University of Technology, Yola \\ E-mail: suleimangambiyo@ymail.com
}

$\begin{array}{ll}\text { Received: September 30, } 2011 & \text { Accepted: October 11, 2011 } \quad \text { Published: February 1, } 2012 \\ \text { doi:10.5539/jfr.v1n1p286 } & \text { URL: http://dx.doi.org/10.5539/jfr.v1n1p286 }\end{array}$

\begin{abstract}
The focus of this paper is to examine the effects of global food crisis on developing countries which most times are considered most vulnerable due to a number of factors ranging from conflicts in the region, to poverty and inequality, and factors that affect policies on agriculture. Issues concerning the use of food as alternative energy sources are still in its infant stages in Africa, and may not be relevant. The paper investigates the impact of capital expenditure on agriculture and credit to agricultural sector on the output of agriculture in Nigeria. Annual data covering 1990 - 2004 were used. Unit roots of the series were examined using Augmented Dickey - Fuller techniques. The overall results indicate that output of agriculture is positively related to capital expenditure on the sector but negatively related to the credit to agriculture. The paper therefore recommends improvements in government capital expenditure on agriculture. Credit policies and institutions should target beneficiaries (rural farmers).
\end{abstract}

Keywords: Agricultural output, Government policies, Access to credit, Capital expenditure

\section{Introduction}

Growing food shortfalls in the global economy had introduced high degree vulnerabilities for Africa and Asia. Global food crisis have become a worldwide phenomenon and its effects are felt all over the world. Food shortages have been attributed to various factors ranging from conflicts around the world, flooding, droughts in Africa, new uses of some crops for energy sources, the biofuels, and the growing needs for ethanol as a source of energy. Other reasons attributed are, environmental factors due to the changing climates around the globe, and growing fuel prices which oil speculators believe will hit $\$ 300$ bench mark before the end of 2008. This affects transport systems, with chain effects on food prices.

Global food crisis has sparked riots around the world; even the developed economies had experienced such riots for example; the strike of heavy vehicles drivers around the world in June 2008 caused by increasing oil prices. In Africa, the situations have reached its high points with riots in most countries of Africa. A report by Peace and Freedom (2008) state how governments and organization react to the growing food crisis: “.......after Vietnam won the Philippine contract by under pricing the world's number one rice exporter, Thailand, a few things happened. The communist government of Vietnam said that the Philippines deal would not commence until at least June, in order to give the government time to distribute rice at home and to assess rice stocks and possible reserves." It also reported that in Bangladesh the army had to be called out to protect the areas where rotten rice is dumped. The poor were savaging and eating rice soaked and rotting.

The situation in Africa calls for urgent concerns due to high costs of foods in the continent. Africa seems to be shifting or detracted by this trend to earmarking huge amounts of the budgets for food and agricultural production rather than growing needs for provisions of much needed infrastructure - good roads, energy needs and recent focus of governments in Africa for empowering the poor and the desired level of growth of the economies ravaged by conflicts and increased poverty levels of the population.

Changes in the population and growth in the developing world has also raised concerns for the short falls in food supply. Population dynamics as defined by Turchin 2001, "the study of how and why population numbers change in time and space'. This is important because changes may bring about positives, in terms of raising a dynamic manpower for countries desiring to belong to the so called 'club' of developed and powerful nations - group of 8 industrialized nations, world nuclear power nations, and so on. The trends in population changes may bring about 
socio-political problems, economic-related problems, relating to growth goals and other dynamic aspects. Abrupt and seemingly inexplicable changes in population numbers have fascinated and puzzled humanity from prehistoric times. This growth also defines the productivity of the population coupled with some auxiliary factors like standards of living, the environment and so on.

Food crisis also defines food security of nations. According to the Food and Agriculture Organization (FAO 2003) of the United Nations, "Food security refers to the availability of food and one's access to it. A household is considered food secure when its occupants do not live in hunger or fear of starvation. Debates around the world which seems to link current food crisis to growing need for alternative energy and current hikes in fuel prices has increased debates for food vs fuel. This is the dilemma regarding the risk of diverting farmland or crops for biofuels production in detriment of the food supply on a global scale. Biofuel production has increased in recent years. Some commodities like maize, sugar cane, or vegetable oil can be used either as food or to make biofuels. For example, since 2006, land that was also formerly used to grow other crops in the United States is now used to grow maize for biofuels, and a larger share of maize is destined to ethanol production, reaching $25 \%$ in 2007 . With global demand for biofuels on the increase due to the oil price increases taking place since 2003, there is also fear of the potential destruction of natural habitats. Environmental groups have raised concerns about this trade-off for several years, but now the debate reached a global scale due to the 2007-2008 world food price crisis.

Global food crisis has called attention of world leaders on the urgency for a global partnership in fighting this crisis. According to report by Reuters of the Rome summit, it has been described as a global crisis pushing 100 million people into hunger, threatening to stoke social and political turmoil and set the fight against world poverty back by seven years. "Now, the food price crisis will be tackled by world leaders who meet in Rome to seek ways of reducing the suffering for the world's poorest people and ensure the Earth can produce more food to sustain an ever growing population. This also echoed the concerns of Jacques Diouf, the head of the United Nations Food and Agriculture Organization (FAO) who called the summit late last year before the full extent of the food price crisis was clear. Also, World Bank President Robert Zoellick underlined the urgency of the problem, announcing \$1.2 billion in loans and grant financing for countries struggling with food and fuel costs. At the Rome food summit (June 15, 2008), the position paper was: "The reasons for food insecurity are mainly to be found in social and economic factors such as poverty and inequality." There are reports that suggest the way forward in the current food crisis. Many such suggestions have been advocated, also adding their voices to the World food summit in Rome, June, 2008. An outlook by the Wall Street Journal written by Bob Davies, suggest four ways, boast research on improving farms yields, invest more in irrigation and rural transportation, power African farms with solar and wind energy and produce biofuels with inedible vegetation, instead of corn.

\section{Literature}

Literature in agriculture and related fields are enormous. There is 'heavy traffic' in this field - studies done by International bodies/institutions like FAO, governments - DFID,USAID that have sponsored researches to assist and develop agricultural sectors in developing countries. Researchers are engaged in researches in various aspects of agricultural productivity. This study builds a simple model for examining how capital expenditure (public expenditure), access to credit effects on output and related fields. This is the contribution of this paper.

The conceptual basis for measuring agricultural output in Nigeria has all times being traced to structural changes of the Nigerian economy - the discovery of oil in the 1970s. Agriculture constitutes the springboard for the growth of the economy and the sources for foreign exchange budget before the advent of oil. According to Obadan, (1983), "agriculture accounted for 97.3 percent of the total share of export in Nigeria." .Nigeria's fortune in the new found wealth affected the agriculture sector from 1973. Continuous decline of agriculture despite huge investments in the sector - establishment of river Basins and rural development, Agricultural Development Programmes, ADP (funded jointly by the World Banks, and Federal, state Governments and the Agricultural Accelerated Programmes, NAFPP), and more than 20 Agricultural Research Institutions, seems to have compounded the rise in oil revenue. This was the beginning of Nigeria declining from a position food exporter to net importer of food.

The principal constraint to the growth of the agricultural sector is the fact that the structure and method of production have remained the same since independence more than four decades ago - because some minor innovations in agricultural investment were not sustained over the years. The United Nations Food and Agriculture Organization rate the productivity of Nigeria's farmland as low to medium - but with medium to good productivity if properly managed by the country. To be effective, and attain higher level of productivity and growth in the agricultural sector there is a need to identify the major factors that determine its growth. This study 
will examine agricultural output and capital expenditure using a model to identify mainly credit availability and how capital expenditure had impacted on output.

An important fact in Nigerian Agriculture, and indeed Africa, is still the fact that most of the literature shows that agriculture growth in Africa remains fundamental to growth and poverty reduction on the continent. "A one percent increase in crop yield reduces the numbers living in under dollar one per day poverty by six and a quarter million, with 95 percent of these in Africa and Asia”. (Thirtle, Lin and Piesse 2003). This statement is always a case in point due to some of the following:

a). The problems associated with the land use policies that had results to communal conflicts

b). The prevalence of HIV/AIDS that affected the labour force participated rate - (see Abdulazeez Abubarkar et al, 2008), and many other literature on HIV/AIDS Scourge in Africa.

c). Conflict zones in Africa which has created an increase in refugees.

d).Climate related problems in Africa and Asia as opined by J.W. Knox, et al (2011).

The global food crisis had therefore made the existing situation (shortfalls experienced in the Africa and the rest of the world) grave from a point view of a cross-country data and reports. Some of the arguments are the fact that the growing trends in food situations shows the complex nature of the demand for and supply of food. Most literature had focused on Agriculture polices, arguments about alternative uses of foods, fuel propelled arguments for soaring food prices, Poverty and inequality arguments, which features in most literature and points to Africans and Asia situation. It defines vulnerability of these groups in most the development literature, it is generally used relative to poverty, and is defined as the ex ante risk that non-poor households will fall below the poverty line and poor households will remain poor (Tesliuc and Lindert, 2002 citing Holzmann, 2001). Defining vulnerability relative to both current and potential future poverty is important from a policy perspective, insofar as poverty is a stochastic phenomenon (Chaudhuri, 2003). In other words, even if poverty rates stay the same, the poor of today may not be the poor of tomorrow, and conversely, the non-poor of today may be the poor of tomorrow.

This study had made a survey of some related literature on the following which have important implications and are critical in aggravating food situations in many economies: (The authors have referred to these reports as basis for myriad problems which sometimes had formed literature and important references in food problem/crisis - for further research in salient aspects like the financial market conditions and commodity speculator activities who are sometimes encouraged to operate under corrupt regimes)

\subsection{Agricultural policies}

There are many reasons why the economy of Africa should grow sufficient food to feed it growing population. Firstly, most of Africa is rural with arable land, except the Sahel regions, coupled with short rainfalls most yields in Africa depended on rain fed. Secondly, bulk of the population in Africa practice some form of agriculture and thirdly, mostly governments in the regions of Africa commit large portions of their budget to the agricultural sector. Where did the Africans miss it?

Current global development policy, the Millennium Development Goals (MDGs), outlined the importance of the agricultural sector. Goal number one, Eradicate extreme poverty and hunger is a great commitment for the growth of the sector. According to World Food Programe (WFP), 75 million people need to be lifted out of poverty in Africa.

Problems have always been levels of commitments of policies in the sector over the years. In Nigeria for instance, the current developmental focus (the 7-point agenda of the regime) places Food security as the topmost points to achieve. Also, backed up by the NEEDs programme and other policies to increase output in the agricultural sector in Nigeria, the microfinance policies, the Agricultural Credit Guarantee Schemes other programmes that provide periodic large funds released in assisting the sector (especially during the Obasango regime in Nigeria), Rural Financing Projects that provide credit facilities for small farmers, development of existing Dams /river basins

(i) Anambra - Imo River Basin

(ii) Benin Owena River Basin

(iii) Chad River Basin

(iv) Hadeja-Jamaare River basin

(v) Cross River Basin

(vi) Lower Benue River Basin 
(vii) Lower Niger River Basin

(viii) Niger-Delta Basin

(ix) Ogun-Osun Basin

(x) Upper Benue River Basin

(xi) Upper Niger River Basin

(xii) Sokoto-Rima River Basin

The Development of the Dams is to encourage an all-year-round farming. Some of agricultural activities (irrigation) have been successful, but most of these Dam projects have remained big liabilities to government in terms of maintenance.

One of the greatest obstacles to increase output in the agricultural sector has been in infrastructure development and inputs (fertilizer) required, and since most farmers depend on rain fed crops, there is need for developing quick yielding crops especially in Northern parts of Nigeria and countries in the Sahel that experience low rainfall in the rainy season. Recent meeting with top managers of the country only took measures for the increase of food through imports in the short run. Long run measure is to cooperate between Agriculture and Water ministry. This is a wait and see situation in the current position of food crisis in Nigeria.

\subsection{Food vs. biofuel arguments (Agflation)}

The rise in food prices has generated a lot of debates overt who the villains are. But there are reports about the rising cost of oil which calls for alternative energy sources. This had led to demand for foods used as energy biofuels and ethanol which are renewable fuels. According to IRIN's reports by the Assistant Director-General of the UN Food and Agriculture Organization (FAO).

\section{(Figure 1)}

"Various studies and think-tanks have come up with estimates of the impact of biofuel on food prices that range from 10 percent to 60 percent." From the graph shown above, rise in food prices is connected to rise in the use of food as source of energy (The so called Agflation). It shows a sharp increase in food prices as a result of increasing use of food for fuel. Supporters of this campaign blame corn-based ethanol and government fuel policies, including other related factors are responsible in hiking prices of food. Most supporters believe that the food -to-fuel policies led to expanded corn planting, which is responsible for changing land use around the world that threatens crucial ecosystem and at the same time, rising demand for corn set off global food price increase, and threatening nations in riots, deeper into poverty and other vices especially in poor countries.

For developing countries that have not experienced use of food for alternative energy sources, the current rise in fuel prices may force governments to a rethink of policies for devoting resources towards the production of foods use for fuel, especially maize and so on.

A report by IRIN (2008); Africa shows signs of increasing African governments considering alternative source of fuel in Congo. "We are working to develop a balance within agriculture in land use between land reserved for food cultivation and land reserved for biofuels," Congolese President Denis Sassou Nguesso said a few days earlier after returning from Rome where he took part in a high-level UN Food and Agriculture Organization (FAO) summit on food security, climate change and biofuels." "The Congo government has therefore set aside 8.2 million hectares of land". According the reports, Congo has serious food shortages.African governments should not be drawn into the production of food use for fuel because of the 850 million people in the world suffering from hunger; some 820 million people are living in the developing countries according FAO. All lands should be used to grow foods in Africa.

\subsection{Fuel prices propelled factors}

The rising fuel prices have affected the global economy, and especially the real sector. The phenomenon of rise in the price of oil (petroleum products) had propelled a rise in prices worldwide boosted energy profits, but crushed the economy. This trend had contributed to hikes in the prices of foods around the world.

Oil also provides most energy for mechanized food production and transport. Higher prices for liquid fuels from petroleum increase the demand for biofuels which may result in diverting some crops from food to energy. Even though per-capita petroleum consumption among the world's poorest people is very low, what petroleum the poor do consume is disproportionately in the form of fossil fuel inputs to the food they eat, especially to any food imported from industrial agriculture powerhouses such as the United States. People who were already living at a 
subsistence level when oil was relatively cheap are extremely vulnerable when oil prices rise, and may simply lack the means to afford enough daily food calories to survive.

In the developing nations for instance, higher fuel prices are glaringly notice to have affects on transports of people and goods. Changes in prices are to a certain extent mostly tied to availability of the commodity (petrol). Periodically in Nigeria, petrol plays a big factor in price hikes. If transport fares increased it immediately have effects on the prices of foods around the markets in Nigeria, and especially in the northern part of Nigeria. Arguments are; not availability of any commodity, but prices increase excludes many from consuming a particular good or service.

\subsection{Poverty and inequality arguments.}

Poverty and inequality has been a big issue in the Millennium Development Goals (MDGs) for Africa and Asia. There are growing concerns that these regions are ranked to be surviving on less than a dollar. Incidence of poverty is high in these regions. There are many factors attributed to this phenomenon, It range from quality of government interventions in agricultural policies (in terms of effective monitoring of issues like farm input distribution, poverty related programmes and income distribution amongst other). That means tackling poverty and the power imbalances that underpin it.

The number of people in sub-Saharan Africa who subsist on less than a dollar a day has almost doubled since 1981, to 313 million people in 2001, representing 46 per cent of the population. Most of Africa's poor and undernourished people live in rural areas. Smallholders, nomadic pastoralists, and women are particularly vulnerable to hunger due to marginalization and neglect. The joint effort promised by African governments and donor governments to eradicate poverty must therefore deliver rural policies that involve and prioritize these vulnerable groups. Even small improvements in what they produce and earn will have a major impact in reducing hunger, as well as driving equitable growth. This should be determined country-by-country, through consultation between governments, civil society and donors, and agricultural producers themselves. However, a key ingredient must be proper investment in long-term rural development programmes and infrastructure, including support for organizations that represent the voices of marginalized groups. African governments have committed themselves to increase their spending on the rural sector to 10 per cent of their budgets. This should be backed by greater external assistance financed from the recent G8 commitments to increase development aid and debt relief.

An important lesson from the flawed market reforms introduced from the 1980s by the International Monetary Fund and World Bank, backed by the major donors, is that rural markets on their own cannot deliver food security. State action is also needed. There is growing evidence, for example, that government policies to stabilise prices, to provide cash transfers or targeted agricultural inputs, can be a more timely and cost-effective way (than emergency food aid) of ensuring food security.

The international community must act to stabilise the volatile commodity prices which create such hardship for African producers. The rich-country trading blocs must stop forcing open African markets for their own benefit, and end the dumping of their subsidized farm produce.

\subsection{Current credit crunch arguments (financial market conditions)}

Credit crisis has introduced liquidity crisis in financial institutions and the ability or inability to create credits for users. According to a report on the wall street journal (2008), "global surge in food and energy prices is being driven primarily by fundamental market conditions, rather than an investment bubble, say the majority of economists in the latest Wall Street Journal forecasting survey"

Credit conditions have consequences on borrowers. Even though economists are of the view that a full scale credit crunch does not exists, the effects has trickle down to most economies around the globe. The effects of this state of affairs have had impacts in big agro allied business, shipping lines and so on. Africa depended on some of these services offered by these institutions for imports and technical partnership. The effects is manifested in slowed imports of agricultural inputs, technology related aspects of agriculture. This ultimately has effects on food prices or availability.

\subsection{Commodity speculators}

Commodity speculators buy wide range of commodities ranging foods and energy and other aspects. The main objective of these speculators is to make profit over time. Commodity speculators apply various strategies in buying and selling in order to earn profit. Their strategies depend on existing business/legal environment within which they operate. In most advanced countries, in the United States for instance, the Wall street Journal (WSJ) made a wide range of survey of commodity speculators over the years. Here's how the speculators drive prices sky-high. 
In Africa, the role of commodity speculators seems to aggravate food situations in most African economies. In Nigeria for instance, speculators seems to have 'government' blessings in their operations. Food meant for the rural poor is most times diverted, sometimes given to government officials who made contacts with local speculators; within a short time such commodities are displayed in local market stalls. The case of fertilizer supply is worst. Small farmers cannot afford the commodity because middlemen (speculators) had fixed higher prices. For instance, government price for fertilizer is N1500 for 2007-2008 farming seasons but the price in the market is N3500, since most soil has been used for many years, the yield is low without fertilizer. This has contributed to low agricultural output in most of rural Nigeria. This is also the state of food imports in Nigeria. Multinationals, which have been contracted to import fertilizer, also aggravate prices of agricultural inputs.

\section{Data and Method of Analysis}

The main focus of this paper is to examine Nigeria's experience over the years and trends (given data available) in agricultural sector, its effects on whether the country is food secure or food insecure. The data used for this study are basically time series covering 1990-2004, that is fifteen (15) years which were sourced from Central Bank of Nigeria (CBN) Statistical bulletin.

\subsection{Model specifications}

Regression model (multiple regressions) is used to analyze the relationship between agricultural output and capital expenditure on agricultural sector and credit on agricultural sector over the period of 15 years $(1990-2004)$ to determine the degree of vulnerability over the years. The model is therefore specified as follows:

$$
\text { LOGAGRIC }=\mathrm{B}_{\mathrm{O}}+\mathrm{B}_{1} \text { LOGCEA }+\mathrm{B}_{2} \mathrm{LOGCAG}+\mu
$$

Where:

$\mathrm{B}_{0}=$ Constant or intercept, $\mathrm{B}_{1}$ and $\mathrm{B}_{2}$ are the coefficients of the explanatory variables of the model.

LOGAGRIC $=$ Log of agricultural output.

LOGCEA $=$ Log of capital expenditure on agricultural sector. bank credit.

LOGCAG $=$ Log of credit on agricultural sector defined as public and private credit as well as community

$$
\mu=\text { white noise error term. }
$$

A priori expectation: $\mathrm{B}_{0}>0, \mathrm{~B}_{1}>0, \mathrm{~B}_{2}>0$

\section{Justification for the model and variables selected.}

Agricultural sector is the major contributor of food in Nigeria hence the need for improvements

to boost its productivity. This can be achieved by increasing capital expenditure, which includes public investments in the sector - heavy farm machinery, ariel sprays of farmland against birds and insects for most of the northern region that grow grains (corn, g/corn, millet) as well increase credit, provided by the Central Bank and managed by Nigerian banks, made available to small holders and microfinance institutions for the sector which justifies the selection of the variables in the model.

\subsection{Econometric Diagnostic Test:}

\section{Unit Root Test}

This study used or adopted Augmented Dickey-Fuller (ADF) Technique to verify the unit root property of the series. Macroeconomic data are generally characterized by stochastic trend which can be removed by differencing. Unit root test is used to test whether the data is stationary or not.

\section{Results and Discussions}

Table 2 contains the multivariate regression results of the model. The results indicate that both the capital expenditure on agricultural sector and credit to agricultural sector are statistically significant (including the constant). Precisely, the coefficient of capital expenditure on agriculture (CEA) is found to be statistically significant at 1 percent level as indicated by its probability value 0.0000 and rightly signed (positive). This, therefore, implies that a unit percent increase in capital expenditure on agriculture raises the output of agriculture (AGRIC) by 16.6 percent. However the coefficient of the other explanatory variable, credit to agricultural sector (CAG), go contrary to the theoretical expectation and found to be negative. The coefficient of credit to agriculture is also found to be statistically significant at 1 percent level as indicated by its probability value 0.0000 though not rightly signed (negative). This, therefore, implies that a unit percent increase in credit to agricultural sector (CAG) decreases the output of agriculture (AGRIC) by 3.73 percent. The constant is also is statistically significant at 5 
percent level as indicated by its probability value 0.0000 and rightly signed (positive). This also indicates that output of agriculture does not depend only on capital expenditure and credit to agricultural.

The $\mathrm{R}^{2} 0.88$ (88\%) implies that 88 percent of total variation in the output of agriculture is explained by regression equation. Coindentally, the goodness of fit of the regression remained high after adjusting for the degrees of freedom as indicated by the adjusted $\mathrm{R}^{2}\left(\mathrm{R}^{2}=0.86\right.$ or $\left.86 \%\right)$. The F-statistic 43.5 , which is a measure of the joint significance of the explanatory variables, and the explanatory power of $R^{2}$ is found to be statistically significant at 1 percent as indicated by the corresponding probability value (0.000003). The model is found not spurious which is indicated by the DW (2.6) greater than $\mathrm{R}^{2}(0.88)$ and $\mathrm{R}^{2}(0.86)$. Since DW (2.6) is high, there is autocorrelation between the disturbance terms.

The results of unit root test are contained in table 3-5. The results show that output of agriculture (LOGAGRIC) and capital expenditure on agriculture (LOGCEA) are both stationary at first difference (d(1)) and 5 percent significance level; while credit to agriculture is stationary at second difference $(\mathrm{d}(2))$ and 5 percent significance.

\section{Conclusions}

The paper investigates the impact of both capital expenditure and credit to agricultural sector on the growth of the output of agriculture in Nigeria and how it relates to the global food crisis. In order to avoid spuriousity of the estimates, the unit roots of the series were verified using Augmented Dickey-Fuller (ADF) technique. The key findings include long-run positive impact of capital expenditure on the growth of agricultural produce while long-run negative impact of credit to agriculture on the output of agriculture. The paper concludes that the output of agriculture over the years under review is on a declining trend, increasing food insecurity in the country despite levels of capital expenditure. Increasing credit may not be necessary but targeting rural farmers who most times do not benefit from such facilities. This category provides 60 percent of all agricultural output in Nigeria, thus agricultural policies that benefit them may be a realistic solution.

\section{Recommendations}

The paper therefore, recommends improvement in government capital expenditure on agriculture, and increase incentive to agricultural sector. Increasing incentives to sector - main players and making sure that such incentive reaches the target beneficiaries (rural farmers). The establishment of more agricultural banks for farmers to access credit and enacting policies and programmes aimed at improving agricultural output are central to the realization of a food secure Nigeria.

Specifically, regional agricultural policies (due to different climatic conditions in the country) as suggested by OneWorld, where most of the underweight children are located in just six states in the North-Eastern Nigerian, which is semi-arid land and encouraging quick yielding variety of crops may reduce the vulnerability index in these regions.

\section{References}

Abdulazeez Abubarkar et al (2008), Concurrent Infection of HIV-1 and HIV-2 Serotypes in Adamawa State Nigeria, World Journal of Medical Sciences 3 (1): 15-18, 2008 IDOSI Publications.

ADB. (2007). High Oil Prices and the African Economy. NESG Economic indicators, Oct-Dec., 13, 4.

AgWeb. (2008). New campaign targets biofuels policies.

BBC News. (2008). The cost of food: Facts and figures, May, 2008.

Blas Javier. (2008). Top Food exporters ease restrictions, Financial Time September 4, 32004, London

Chaudhuri, S. (2003). Assessing Vulnerability to Poverty: Concepts, Empirical Methods and Illustrative Examples. Mimeo. Department of Economics, Columbia University.

Davis, Bob. (2008). "Four Ways to Ease A Global Food Crisis over next year." Wall Street Journal, May, 12.

DFID. (2005). Growth and Poverty reduction: the role of Agriculture, Department for International Development (DFID) Policy paper, Abuja, Nigeria.

ENS (Environment News Service) (2008). UN: Biofuel Production 'Criminal Path' to Global Food Crisis.

Esther Duflo. (2008). Food Prices, The need for insurance.

FAO. (2007), Crop Prospects and food Situation, No.6. Dec.

FAO. (2002). Towards 2015/2030: An FAO Perspectives and summary report. Population and Development Review, Vol. 29, No. 2. 
Federal Government of Nigeria. (2008). Nigeria: Food security.

Food Security. (2008). Http:www//en.wikipedia.org/wikki/food_insecrity.

Food Summit. (2008). High-level conference on world food security: the changes of climate and Bioenergy, June 3-5.

Fusako Ishinda, et al. (2001). Sustaining Soil Fertility in West Africa”, Soil Science Society of America (SSA) publication Number 58, Madison Wisconsin USA.

IRIN. (2008). Biofuels, Http:www//irinnews.org/InDepth Main.

Izzo, Phil. (2008). Bubble is not Big factor in Inflation. Wall Street Journal, May 2, 2008, A2.

James, O. A. (2006). Chronicles of River Basins management in Nigeria. Lagos, Nigeria

Jhingan, M. I. (2003). Advanced Economic Theory (12 ${ }^{\text {th }}$ Edition), Vrinda Publication Ltd, Delhi, India.

Joe D. C. (2008). NGO warms of Global catastrophe.

John, G. E. (2008). Global food crisis: Impact acutely felt from Africa to Asia, Peace and freedom.

Knox, J. W., T. M. Hess, A. Daccache \& M. Perez Ortola. (2011). What are the projected impacts of climate change on food crop productivity in Africa and S Asia? DFID Systematic Review.

Li Onesto. (2008). The global food Crisis and the ravenous system of capitalism, Counter Current.org.

M. I., Obadan. (1983). Diversification: Strategy for Nigerian Economy. NES, Lagos, Nigeria.

Okuneye, P. A. Rising cost of Prices and food insecurity in Nigeria and its implications for poverty reduction, printed for FAO, ILO, UNDP and UNEP. CBN Economic and Financial Review, Vol.39, No.4.

One World. (2011). Food Security in Nigeria.

Owen, Richard. (2008). Food summit hammers out for world's hungry. General Health Council, June 4.

Peluola Adewale. (2008). World Food Crisis: Total failure of capitalism.

Prism Webcast News. (2008). Deadly greed: the Role of speculators in the global food crisis.

Reuters. (2008). World Leaders tackle food crisis at Rome summit, 30 May, 2008.

Submitter. (2008). SAHEL: Backgrounder on Sahel, West Africa's poorest Region.

Tesliuc, E., \& K. Lindert. (2002). Vulnerability: A Quantitative and Qualitative Assessment. Guatemala Poverty Assessment Program. Washington, D. C.: World Bank.

Turchin, Peter. (2001). Complex Population Dynamics: A theoretical/Empirical synthesis, USA, Princeton University Press.

UNDP Nigeria. (2008), Millennium Development Goals at a Glance.

Walden Bello. (2008). How to manufacture a global food crisis: lessons from the World Bank, IMF and WTO, Transnational Institute.

Wikipedia. (2006). How a credit crunch may hurt the world economy. 
Table 1. Agriculture: GDP and Financial/Credit Flows in billion from 1990 -2004

\begin{tabular}{|l|l|l|l|l|l|l|}
\hline Year & Total GDP & $\begin{array}{l}\text { Agric. } \\
\text { GDP }\end{array}$ & $\begin{array}{l}\% \\
\text { Contribution to } \\
\text { GDP }\end{array}$ & $\begin{array}{l}\text { Capital } \\
\text { Expenditure } \\
\text { on Agric } \\
\text { (FGN) }\end{array}$ & \multicolumn{2}{l|}{ Credit to Agric } \\
\hline & & & & & $\begin{array}{l}\text { Public and } \\
\text { Private }\end{array}$ & $\begin{array}{l}\text { Community } \\
\text { Bank }\end{array}$ \\
\hline 1990 & 257.87 & 35.80 & 13.9 & 1.60 & 6.93 & - \\
\hline 1991 & 320.25 & 36.50 & 11.4 & 1.22 & 8.00 & - \\
\hline 1992 & 544.33 & 37.30 & 6.9 & 0.94 & 11.00 & - \\
\hline 1 S993 & 691.61 & 37.80 & 5.5 & 2.18 & 25.00 & - \\
\hline 1994 & 911.09 & 35.60 & 4.2 & 2.18 & 25.00 & - \\
\hline 1995 & 1960.69 & 40.00 & 2.0 & 2.41 & 35.00 & - \\
\hline 1996 & 2740.46 & 41.70 & 1.5 & 3.89 & 44.00 & - \\
\hline 1997 & 2835.00 & 43.50 & 1.5 & 6.25 & 37.00 & - \\
\hline 1998 & 2721.51 & 45.60 & 1.7 & 4.33 & 19.00 & - \\
\hline 1999 & 3250.67 & 47.60 & 1.5 & 8.88 & 31.00 & - \\
\hline 2000 & 4547.10 & 48.99 & 1.1 & 6.91 & 41.00 & 1.61 \\
\hline 2001 & 5187.90 & 51.47 & 1.0 & 5.76 & 50.50 & 0.08 \\
\hline 2002 & 5465.30 & 64.41 & 1.2 & 32.36 & NA & 0.39 \\
\hline 2003 & 7191.10 & 68.02 & 0.9 & 8.57 & NA & 0.63 \\
\hline 2004 & 8553.30 & 72.20 & 0.8 & 38.67 & NA & 0.48 \\
\hline S0urs & CB & & & & - \\
\hline
\end{tabular}

Sources: CBN (2003), Cotemporary Economic policy issues, edited by Nnanna et al Pg198; CBN Annual Report 2004 pg 114 and 131, CBN statistics Bulletin Vol.2, 1999, pg 119; Esthiobo Samuel Shola (2008).

Table 2. Regression results using observations 1990-2004 $(n=15)$ Dependent variable: LOGAGRIC

Dependent Variable: LOGAGRIC

Method: Least Squares

Date: 08/26/11, Time: 20:24

Sample: 19902004

Included observations: 15

\begin{tabular}{|l|r|r|r|r|}
\hline \multicolumn{1}{|c|}{ Variable } & Coefficient & Std. Error & t-Statistic & Prob. \\
\hline C & 1.589693 & 0.032118 & 49.49547 & 0.0000 \\
\hline LOGCEA & 0.166187 & 0.026337 & 6.309984 & 0.0000 \\
\hline LOGCAG & -0.037299 & 0.016660 & -2.238902 & 0.0449 \\
\hline R-squared & 0.878718 & Mean dependent var & 1.661067 \\
\hline Adjusted R-squared & 0.858505 & S.D. dependent var & 0.102762 \\
\hline S.E. of regression & 0.038655 & Akaike info criterion & -3.491432 \\
\hline Sum squared resid & 0.017930 & Schwarz criterion & -3.349822 \\
\hline Log likelihood & 29.18574 & Hannan-Quinn criter. & -3.492940 \\
\hline F-statistic & 43.47162 & Durbin-Watson stat & 2.621608 \\
\hline Prob(F-statistic) & 0.000003 & & & \\
\hline
\end{tabular}

Source: Computer output. 
Table 3. Unit Root Test for log of output of agriculture

Null Hypothesis: D(LOGAGRIC) has a unit root

Exogenous: Constant

Lag Length: 0 (Automatic - based on SIC, maxlag=3)

\begin{tabular}{|l|c|l|c|c|}
\hline \multicolumn{2}{|l|}{} & & t-Statistic & Prob. $^{*}$ \\
\hline \multicolumn{2}{|c|}{ Augmented Dickey-Fuller test statistic } & -3.409973 & 0.0306 \\
\hline Test critical values: & $1 \%$ level & & -4.057910 & \\
\hline & $5 \%$ level & & -3.119910 & \\
\hline & $10 \%$ level & & -2.701103 & \\
\hline
\end{tabular}

Augmented Dickey-Fuller Test Equation

Dependent Variable: D(LOGAGRIC,2)

Method: Least Squares

Date: 08/26/11 Time: 20:33

Sample (adjusted): 19922004

Included observations: 13 after adjustments

\begin{tabular}{|l|r|r|r|r|}
\hline \multicolumn{1}{|c|}{ Variable } & Coefficient & Std. Error & t-Statistic & Prob. \\
\hline D(LOGAGRIC(-1)) & -1.018571 & 0.298704 & -3.409973 & 0.0058 \\
\hline \multicolumn{1}{|c|}{ C } & 0.023183 & 0.010321 & 2.246217 & 0.0462 \\
\hline R-squared & 0.513875 & Mean dependent var & 0.001346 \\
\hline Adjusted R-squared & 0.469682 & S.D. dependent var & 0.040074 \\
\hline S.E. of regression & 0.029183 & Akaike info criterion & -4.089829 \\
\hline Sum squared resid & 0.009368 & Schwarz criterion & -4.002913 \\
\hline Log likelihood & 28.58389 & Hannan-Quinn criter. & -4.107694 \\
\hline F-statistic & 11.62792 & Durbin-Watson stat & 2.020674 \\
\hline Prob(F-statistic) & 0.005826 & & \\
\hline
\end{tabular}

Source: Computer output. 
Table 4. Unit Root Test for log of capital expenditure on agriculture

Null Hypothesis: D(LOGCEA) has a unit root

Exogenous: Constant

Lag Length: 1 (Automatic - based on SIC, maxlag=3)

\begin{tabular}{|c|c|l|l|l|}
\hline & & & t-Statistic & Prob. $^{*}$ \\
\hline \multicolumn{2}{|c|}{ Augmented Dickey-Fuller test statistic } & -6.756561 & 0.0002 \\
\hline Test critical values: & $1 \%$ level & & -4.121990 & \\
\hline & $5 \%$ level & & -3.144920 & \\
\hline & $10 \%$ level & & -2.713751 & \\
\hline
\end{tabular}

Augmented Dickey-Fuller Test Equation

Dependent Variable: D(LOGCEA,2)

Method: Least Squares

Date: 08/27/11 Time: 04:17

Sample (adjusted): 19932004

Included observations: 12 after adjustments

\begin{tabular}{|l|r|r|r|r|}
\hline \multicolumn{1}{|c|}{ Variable } & Coefficient & Std. Error & t-Statistic & Prob. \\
\hline D(LOGCEA(-1) & -2.996129 & 0.443440 & -6.756561 & 0.0001 \\
\hline D(LOGCEA(-1),2) & 0.710519 & 0.266317 & 2.667945 & 0.0257 \\
\hline C & 0.302547 & 0.065381 & 4.627421 & 0.0012 \\
\hline R-squared & 0.942026 & Mean dependent var & 0.063975 \\
\hline Adjusted R-squared & 0.929143 & S.D. dependent var & 0.663256 \\
\hline S.E. of regression & 0.176552 & Akaike info criterion & -0.418086 \\
\hline Sum squared resid & 0.280535 & Schwarz criterion & -0.296859 \\
\hline Log likelihood & 5.508513 & Hannan-Quinn criter. & -0.462968 \\
\hline F-statistic & 73.12127 & Durbin-Watson stat & 2.223971 \\
\hline Prob(F-statistic) & 0.000003 & & & \\
\hline
\end{tabular}

Source: Computer output. 
Table 5. Unit Root Test for log of credit to agricultural sector

Null Hypothesis: D(LOGCAG,2) has a unit root

Exogenous: Constant

Lag Length: 2 (Automatic - based on SIC, maxlag=3)

\begin{tabular}{|l|c|l|c|c|}
\hline & & & t-Statistic & Prob. $^{*}$ \\
\hline Augmented Dickey-Fuller test statistic & -5.933900 & 0.0011 \\
\hline Test critical values: & $1 \%$ level & & -4.297073 & \\
\hline & $5 \%$ level & & -3.212696 & \\
\hline & $10 \%$ level & & -2.747676 & \\
\hline
\end{tabular}

Augmented Dickey-Fuller Test Equation

Dependent Variable: D(LOGCAG,3)

Method: Least Squares

Date: 08/27/11 Time: 04:25

Sample (adjusted): 19952004

Included observations: 10 after adjustments

\begin{tabular}{|l|r|r|r|r|}
\hline \multicolumn{1}{|c|}{ Variable } & Coefficient & Std. Error & t-Statistic & Prob. \\
\hline D(LOGCAG(-1),2) & -5.771409 & 0.972616 & -5.933900 & 0.0010 \\
\hline D(LOGCAG(-1),3) & 3.663451 & 0.852252 & 4.298555 & 0.0051 \\
\hline D(LOGCAG(-2),3) & 2.558567 & 0.736959 & 3.471792 & 0.0133 \\
\hline C & -0.273876 & 0.189914 & -1.442108 & 0.1994 \\
\hline R-squared & 0.947097 & Mean dependent var & 0.003020 \\
\hline Adjusted R-squared & 0.920646 & S.D. dependent var & 1.914821 \\
\hline S.E. of regression & 0.539404 & Akaike info criterion & 1.892470 \\
\hline Sum squared resid & 1.745739 & Schwarz criterion & 2.013504 \\
\hline Log likelihood & -5.462349 & Hannan-Quinn criter. & 1.759696 \\
\hline F-statistic & 35.80505 & Durbin-Watson stat & 2.138163 \\
\hline
\end{tabular}

Source: Computer output.

ENERGY AND FOOD PRICES, 1992-2008

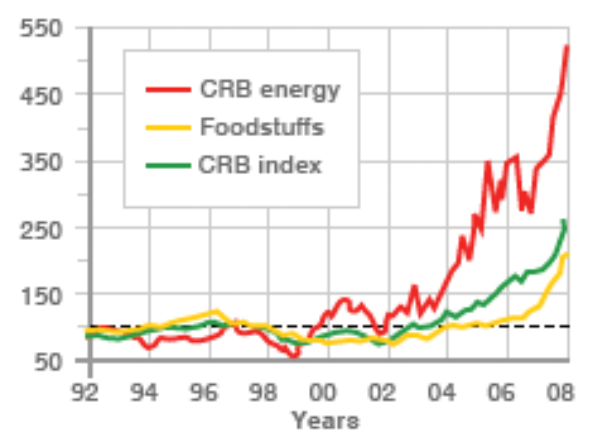

US ETHANOL PRODUCTION 1995-2006

Litrea (billions)

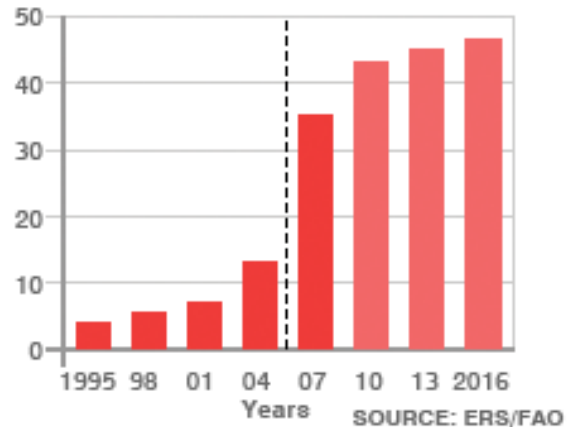

Figure 1. The Commodity Research Bureau and the FAO show a take off in energy prices, before food prices start to rise 